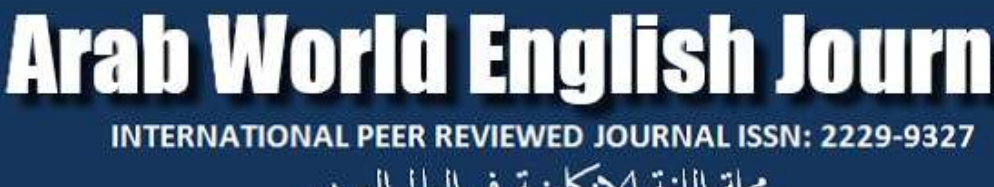 \\ بجاة اللغة الوكليزية في العالم العربي
}

Arab World English Journal (AWEJ) Volume 9. Number 1. March 2018

DOI: https://dx.doi.org/10.24093/awej/vol9no1.10

Pp. 134- 145

\section{Writing for Comprehension in Prose Fiction Analysis: The Students' Voices}

\author{
Lestari Setyowati \\ English Education Study Program, STKIP PGRI Pasuruan, \\ Indonesia \\ Sony Sukmawan \\ Indonesian and Culture EducationFaculty of Cultural Studies, \\ Brawijaya University, Malang, Indonesia
}

\begin{abstract}
:
Literary appreciation and language teaching have long been associated with two different constructs. However, with careful selection and planning, literary study and language teaching can be integrated for the benefits of language learning as well as for literary appreciation. This study is attempted to investigate (i) the students' opinion in relation to the effective way of understanding the intrinsic elements of prose fiction,(ii) their opinion in relation to analyzing fictions in the form of an essay, and (iii) what they learn in terms of the literary aspects and writing aspects. The design the study is content analysis design through document analysis. The participants of the study were 31 students of English Education Study program who took prose subject in College of Teacher Training and Education of Indonesian Teachers Association (STKIP PGRI) in Pasuruan, East Java, Indonesia.. The data was taken from the students reflection writing which was collected in the end of the semester after they joined prose subject class. Thus, the instrument used was mainly documentation. To help the researchers categorized and analyzed the data, some codifications were used. The finding shows the majority of the students believe making an essay to analyze fictions is the effective way to understand the intrinsic elements of prose and help them in sharpening their ability to read and write. The result of the study also shows that writing essays to analyze fictions give some benefits for the students' knowledge in how to write well as well as in comprehending the literary aspects of a fictions.
\end{abstract}

Key words: essay, fictions, prose analysis, students' perception, writing for comprehension

Cite as: Setyowati, L., \& Sukmawan, S. (2018). Writing for Comprehension in Prose Fiction Analysis: The Students' Voices. Arab World English Journal, 9 (1).

DOI: https://dx.doi.org/10.24093/awej/vol9no1.10 